\title{
Characterisation and cross-amplification of polymorphic microsatellite loci in ant-associated root-aphids
}

\author{
A. B. F. Ivens • D. J. C. Kronauer • \\ J. J. Boomsma
}

Received: 28 June 2010/Accepted: 20 July 2010/Published online: 1 August 2010

(C) The Author(s) 2010. This article is published with open access at Springerlink.com

\begin{abstract}
Twenty-six polymorphic microsatellite loci were developed for four species of ant-associated rootaphids: Geoica utricularia, Forda marginata, Tetraneura ulmi and Anoecia corni. We found up to 9 alleles per locus, with an average of 4.8 . We also report polymorphic crossamplification of eleven of these markers between different pairs of study species. Furthermore, we tested previously published aphid microsatellites and found one locus developed for Pemphigus bursarius to be polymorphic in G. utricularia. These microsatellite markers will be useful to study the population structure of aphids associated with the ant Lasius flavus and possibly other ants. Such studies are relevant because: 1. L. flavus mounds and their associated flora and fauna are often key components in protected temperate grasslands, and 2. L. flavus and its diverse community of root-aphids provide an interesting model system for studying the long-term stability of mutualistic interactions.
\end{abstract}

Keywords Microsatellites - Root-aphids - Mutualism · Aphidoidea (Hemiptera) · Pemphigidae $\cdot$ Anoeciidae

\footnotetext{
A. B. F. Ivens $(\square)$

Theoretical Biology Group, Centre for Ecological and Evolutionary Studies, University of Groningen, P.O. Box 11103, 9700 CC Groningen, The Netherlands e-mail: A.B.F.Ivens@rug.nl
}

A. B. F. Ivens - D. J. C. Kronauer - J. J. Boomsma Centre for Social Evolution, Department of Biology, University of Copenhagen, Universitetsparken 15, 2100 Copenhagen, Denmark

D. J. C. Kronauer

Museum of Comparative Zoology, Harvard University, 26 Oxford Street, Cambridge, MA 02138, USA
Mutualistic interactions between species are widespread and play key roles in ecosystem stability and diversity (Stachowicz 2001; Bastolla et al. 2009). In Northwest Europe, the yellow meadow ant Lasius flavus keeps up to fourteen species of mutualistic root-aphids in its nests (Pontin 1978; Heie 1980; Godske 1991). The ants actively tend the aphids, which provide them with honeydew (Pontin 1978). The nest mounds are markers of high grassland biodiversity and long-term habitat stability (Dean et al. 1997; Blomqvist et al. 2000; Lenoir 2009). However, despite the decline of European temperate grasslands in recent decades and the associated losses in plant and invertebrate biodiversity (WallisDeVries et al. 2002), neither the sociobiology of the ants (but see Boomsma et al. 1993), nor the biology of the root-aphids (Pontin 1978; Godske 1991, 1992) have been extensively studied. To facilitate molecular ecological approaches in the study of this mutualism, we developed DNA microsatellite markers for the four commonest species: Forda marginata, Tetraneura ulmi, Geoica utricularia and Anoecia corni.

Samples for genomic library construction for Forda marginata, Tetraneura ulmi, and Anoecia corni were collected in 2007 from an ant-nest on the Dutch island of Schiermonnikoog $\left(53^{\circ} 29^{\prime} 03.5^{\prime \prime} \mathrm{N} ; 6^{\circ} 13^{\prime} 46.1^{\prime \prime} \mathrm{E}\right)$ whereas Geoica utricularia was collected near Dejret, Denmark $\left(56^{\circ} 12^{\prime} 54.2^{\prime \prime} \mathrm{N} ; 10^{\circ} 24^{\prime} 48.2^{\prime \prime} \mathrm{E}\right)$. All samples for molecular analysis were preserved in $96 \%$ ethanol.

Genomic DNA was extracted using the QIAGEN DNeasy Blood \& Tissue kit and enriched for poly-CA and poly-CT microsatellite containing fragments using the protocol by Rütten et al. (2001). We designed PCR primers for the flanking regions of repetitive motifs using the webbased software Primer 3 (Rozen et al. 2000).

Primers were tested on Schiermonnikoog samples collected in 2007, 2008 and 2009 and on samples collected 


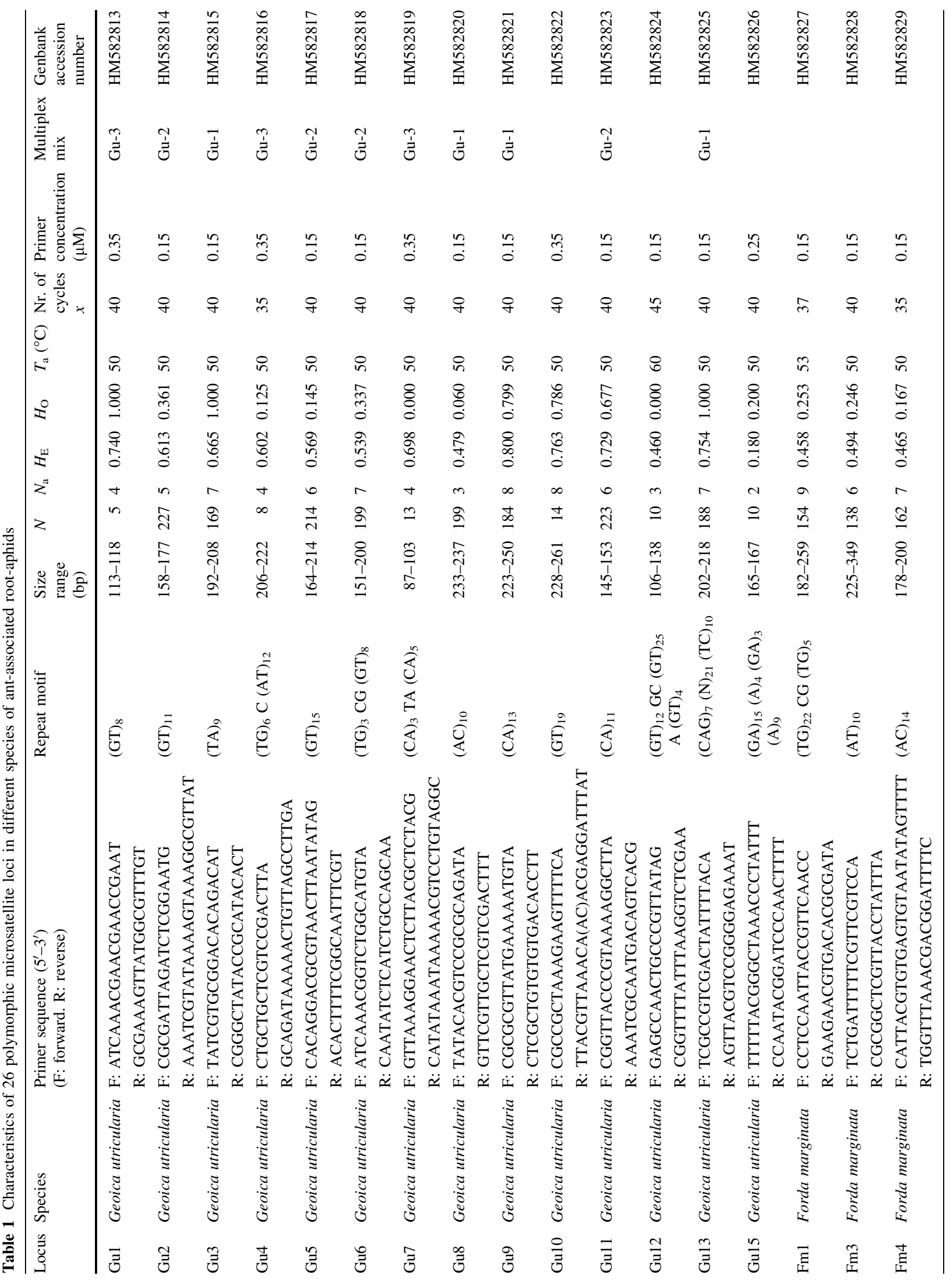




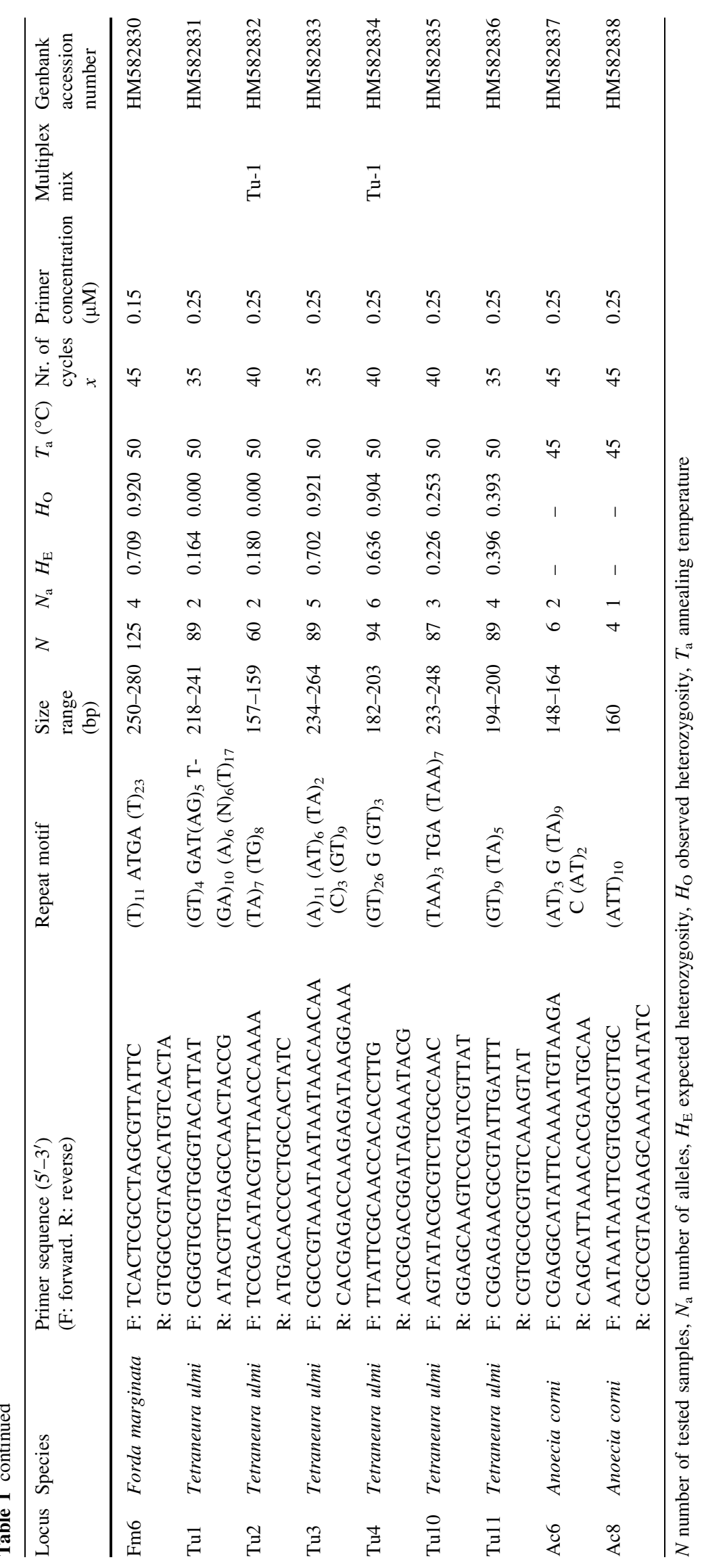


near Dejret in 2007 (Anoecia spp.). DNA for microsatellite screening was extracted using $200 \mu \mathrm{l} 20 \%$-Chelex ${ }^{\circledR} 100$ resin (Fluka) (Walsh et al. 1991). PCR-cocktails had a total volume of $10 \mu \mathrm{l}$, consisting of $0.8 \mathrm{mM}$ dNTPs, $2 \mathrm{mM}$ $\mathrm{MgCl}_{2}, 1 \times$ PCR buffer, $0.25 \mathrm{U}$ AmpliTaq Gold ${ }^{\circledR}$ DNA Polymerase (Applied Biosystems), $1 \mu$ of DNA template and a varying concentration of primers (Table 1). Several primer pairs were multiplexed in PCR (Table 1). The amplification conditions were $95^{\circ} \mathrm{C}$ for $5 \mathrm{~min}, x$ number of cycles of $95^{\circ} \mathrm{C}$ for $30 \mathrm{~s} ., T_{\mathrm{a}}$ for $30 \mathrm{~s}$ and $72^{\circ} \mathrm{C}$ for $30 \mathrm{~s}$ (1 min for Gu3, Gu8, Gu9, Gu10 and Gu13) and a final extension of $15 \mathrm{~min}$ at $72^{\circ} \mathrm{C}$. The respective $x$ and $T_{\mathrm{a}}$ for each primer are listed in Tables 1 and 2.

Amplified fluorescent labeled PCR-products were run on an ABI-PRISM 3130XL (Applied Biosystems) sequencer and chromatograms were analyzed in Genemapper (Applied Biosystems). Expected and observed heterozygosities and deviations from Hardy-Weinberg Equilibrium (HWE) were determined using GENALEX 6.2 (Peakall and Smouse 2006). Occurrence of Linkage Disequilibrium (LD) was assessed using Genepop 4.0 (Rousset 2008).

The fourteen markers developed for Geoica utricularia were tested on 5-227 aphids. All markers were polymorphic, with 5.3 alleles per locus on average (Table 1). The four polymorphic markers for Forda marginata were tested together with three cross-amplifying markers (Gu6, Gu11, Gu13) on 125-162 aphids yielding 6.0 alleles on average (Tables 1 and 2). The six microsatellite markers for Tetraneura ulmi had 3.7 alleles on average in 60-94 tested aphids (Table 1). Observed and expected heterozygosities are given in Tables 1 and 2. Since all species reproduce asexually, deviations from HWE and presence of LD are expected (Ivens et al., in preparation). All loci indeed showed significant deviation from HWE, except for Gu15 in Geoica utricularia, Fm4 and Gu11 in Forda formicaria, and Tu10 in Tetraneura ulmi. In G. utricularia the majority of the loci pairs $(65 \%)$ had significant LD, with most pairs not in LD involving Gu1 and Gu15. All pairs of T. ulmi were in LD, except for Tu10-Tu2, Tu10-Tu1, Tu2-Tu11 and Tu1-Tu11. In F. marginata, all loci pairs were in LD.

The two primer pairs developed for the genus Anoecia amplified across Anoecia species but were not extensively tested. We merely report these loci here for future reference.

Cross-amplification was tested for all markers except Gu12 and Fm5 (Table 2), yielding eleven markers that amplified in one or more additional species. Moreover, most markers used (species specific and cross-amplified) for Forda marginata were also suitable for the sibling species Forda formicaria. The loci Fm3, Fm4, Fm6 and Gu13 proved to be diagnostic for distinguishing between $F$. marginata and $F$. formicaria (Table 2). Three markers from Pemphigus bursarius (Pb02 (Miller et al. 2000)) and P. spyrothecae (97PS12 and 98PS8 (Johnson et al. 2000)) were tested for cross-amplification in our focal species, but only $\mathrm{Pb} 02$ reliably cross-amplified in Geoica utricularia (Table 2).

Although we enriched specifically for $(\mathrm{CA})_{\mathrm{n}}$ and $(\mathrm{CT})_{\mathrm{n}}$ repeats, the aphid DNA appeared to be especially AT-rich, including repeats that were suitable for microsatellite

Table 2 Cross-amplifications of microsatellite markers in different species of ant-associated root-aphids

\begin{tabular}{lllllllllll}
\hline Locus & $\begin{array}{l}\text { Cross-amplified } \\
\text { species }\end{array}$ & $\begin{array}{l}\text { Size } \\
\text { range (bp) }\end{array}$ & $N$ & $N_{\mathrm{a}}$ & $H_{\mathrm{E}}$ & $H_{\mathrm{O}}$ & $T_{\mathrm{a}}\left({ }^{\circ} \mathrm{C}\right)$ & Nr. of cycles $x$ & $\begin{array}{l}\text { Primer } \\
\text { concentration }(\mu \mathrm{M})\end{array}$ & $\begin{array}{l}\text { Genbank accession } \\
\text { number }\end{array}$ \\
\hline Gu6 & Forda marginata & $151-176$ & 159 & 5 & 0.681 & 0.672 & 49 & 40 & 0.15 & HM582818 \\
Gu11 & Forda marginata & $135-147$ & 162 & 6 & 0.489 & 0.234 & 49 & 40 & 0.15 & HM582823 \\
Gu13 & Forda marginata & $143-178$ & 159 & 5 & 0.430 & 0.000 & 45 & 45 & 0.15 & HM582825 \\
Tu11 & Forda marginata & - & 2 & - & - & - & 49 & 40 & 0.15 & HM582836 \\
Fm3 & Forda formicaria & 121 & 18 & 1 & 0.000 & 0.000 & 50 & 40 & 0.15 & HM582828 \\
Fm4 & Forda formicaria & $174-178$ & 18 & 3 & 0.495 & 0.777 & 50 & 35 & 0.15 & HM582829 \\
Fm6 & Forda formicaria & $206-291$ & 18 & 2 & 0.500 & 1.000 & 50 & 45 & 0.15 & HM582830 \\
Gu6 & Forda formicaria & $151-152$ & 17 & 2 & 0.110 & 0.000 & 49 & 40 & 0.15 & HM582818 \\
Gu11 & Forda formicaria & $142-146$ & 18 & 3 & 0.439 & 0.277 & 49 & 40 & 0.15 & HM582823 \\
Gu13 & Forda formicaria & 156 & 19 & 1 & 0.000 & 0.000 & 45 & 45 & 0.15 & HM582825 \\
Fm1 & Anoecia corni, A. zirnitsi & $110-134$ & 7 & 3 & - & - & 45 & 45 & 0.25 & HM582827 \\
Tu2 & Anoecia corni, A. zirnitsi & $137-148$ & 3 & 2 & - & - & 45 & 45 & 0.25 & HM582832 \\
Tu11 & Anoecia corni, A. zirnitsi & $69-126$ & 7 & 5 & - & - & 45 & 45 & 0.25 & HM582836 \\
Ac 8 & Anoecia zirnitsi, A. major & $130-146$ & 2 & 2 & - & - & 45 & 45 & 0.25 & HM582838 \\
Pb02 & Geoica utricularia & $118-124$ & 8 & 2 & - & - & 50 & 40 & 0.20 & AF267192 \\
\hline
\end{tabular}

$N$ number of tested samples, $N_{\mathrm{a}}$ number of alleles, $H_{\mathrm{E}}$ expected heterozygosity, $H_{\mathrm{O}}$ observed heterozygosity, $T_{\mathrm{a}}$ annealing temperature

${ }^{a}$ Developed by Miller et al. 2000 for the lettuce root-aphid Pemphigus bursarius 
design. This observation is in accordance with earlier findings (Weng et al. 2007).

In conclusion, the 26 newly developed microsatellite markers presented here cover a large proportion of the known root-aphid fauna associated with L. flavus and other ant species (Heie 1980), and will be useful for detailed studies of the ecology and evolution of this mutualistic association.

Acknowledgments This study was supported by a $\mathrm{PhD}$-Grant from the Centre for Ecological and Evolutionary Studies, University of Groningen and grants from the Pieter Langerhuizen Fund and the Nicolaas Mulerius Foundation, awarded to A.B.F.I., as well as a grant from the Danish National Research Foundation to J.J.B. that funded D.J.C.K.'s postdoctoral work in Copenhagen. The authors would like to thank Sylvia Mathiasen, Thijs Janzen and Elzemiek Geuverink for help in the laboratory and in the field, Ole E. Heie and Maurice Jansen for help with aphid taxonomy and Franz J. Weissing and Ido Pen for discussion.

Open Access This article is distributed under the terms of the Creative Commons Attribution Noncommercial License which permits any noncommercial use, distribution, and reproduction in any medium, provided the original author(s) and source are credited.

\section{References}

Bastolla U, Fortuna MA, Pascual-Garcia A, Ferrera A, Luque B, Bascompte J (2009) The architecture of mutualistic networks minimizes competition and increases biodiversity. Nature 458(7241):1018-1091. doi:10.1038/nature07950

Blomqvist MM, Olff H, Blaauw MB, Bongers T, Van der Putten WH (2000) Interactions between above- and belowground biota: importance for small-scale vegetation mosaics in a grassland ecosystem. Oikos 90(3):582-598

Boomsma JJ, Wright PJ, Brouwer AH (1993) Social structure in the ant Lasius flavus-multi-queen nests or multi-nest mounds. Ecol Entomol 18(1):47-53

Dean WRJ, Milton SJ, Klotz S (1997) The role of ant nest-mounds in maintaining small-scale patchiness in dry grasslands in central Germany. Biodivers Conserv 6(9):1293-1307
Godske L (1991) Aphids in nests of Lasius flavus F. in Denmark I: faunistic description. Entomol Meddr 59(3):85-89

Godske L (1992) Aphids in nests of Lasius flavus F. in Denmark II: population dynamics. Entomol Meddr 60(1):21-26

Heie OE (1980) The Aphidoidea (Hemiptera) of Fennoscandia and Denmark. I. Fauna Entomol Scand 9:1-236

Johnson PCD, Llewellyn KS, Amos W (2000) Microsatellite loci for studying clonal mixing, population structure and inbreeding in a social aphid, Pemphigus spyrothecae (Hemiptera: Pemphigidae). Mol Ecol 9(9):1445-1446

Lenoir L (2009) Effects of ants on plant diversity in semi-natural grasslands. Arthropod Plant Interact 3(3):163-172. doi:10.1007/ s11829-009-9066-7

Miller NJ, Birley AJ, Tatchell GM (2000) Polymorphic microsatellite loci from the lettuce root aphid, Pemphigus bursarius. Mol Ecol 9(11):1951-1952

Peakall R, Smouse PE (2006) Genalex 6: genetic analysis in excel. Population genetic software for teaching and research. Mol Ecol Notes 6(1):288-295. doi:10.1111/j.1471-8286.2005.01155.x

Pontin AJ (1978) Numbers and distribution of subterranean aphids and their exploitation by the ant Lasius flavus (Fabr.). Ecol Entomol 3(3):203-207

Rousset F (2008) GENEPOP '007: a complete re-implementation of the GENEPOP software for Windows and Linux. Mol Ecol Res 8:103-106

Rozen S, Skaletsky HJ (2000) Primer3 on the WWW for general users and for biologist programmers. In: Krawetz S, Misener S (eds) Bioinformatics methods and protocols: methods in molecular biology. Humana Press, Totowa, NJ, pp 365-386

Rütten K, Schulz I, Olek K, Uhl G (2001) Polymorphic microsatellite markers in the spider Pholcus phalangioides isolated from a library enriched for CA repeats. Mol Ecol Notes 1(4):255-257

Stachowicz JJ (2001) Mutualism, facilitation, and the structure of ecological communities. Bioscience 51(3):235-246

WallisDeVries MF, Poschlod P, Willems JH (2002) Challenges for the conservation of calcareous grasslands in Northwestern Europe: integrating the requirements of flora and fauna. Biol Conserv 104(3):265-273

Walsh PS, Metzger DA, Higuchi R (1991) Chelex 100 as a medium for simple extraction of DNA for PCR-based typing from forensic material. Biotechniques 10(4):506-513

Weng Y, Azhaguvel P, Michels GJ, Rudd JC (2007) Cross-species transferability of microsatellite markers from six aphid (Hemiptera: Aphididae) species and their use for evaluating biotypic diversity in two cereal aphids. Insect Mol Biol 16(5):613-622. doi:10.1111/j.1365-2583.2007.00757.x 